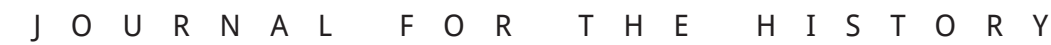

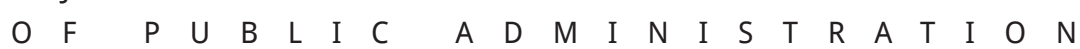

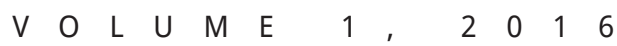

$\begin{array}{lllllllllll}P & A & G & E & 1 & 7 & 3 & - & 1 & 9 & 2\end{array}$

D O I : $10.2478 /$ ADHI-2018-0010

\title{
The Vaccine and Its Simulacra: Agnotology, Ontology and Biopolitics in France, 1800-1865
}

JEAN-BAPTISTE FRESSOZ

When in 1798, the English doctor Edward Jenner revealed the existence of a mysterious cow disease which immunised against smallpox, ${ }^{1}$ vaccination immediately became a political affair. In the total war in which the European states were then engaged, optimisation of life played a critical role: as early as the 1800 s, vaccination was made compulsory in the armed forces of Britain, Prussia and France. In France, the vigour of the first vaccination campaigns (by 1805 there were at least 400,000 people vaccinated) fit into a context of mobilisation for war. According to one doctor, the new virus was supposed to produce »a magnificent race of men [...] who would be able to compel foreign respect for the State «. ${ }^{2}$ In 1804, the Minister of the Interior, Jean-Antoine Chaptal, had just established the prefectoral system when he ordered vaccination to be its priority mission: "no other subject calls for your attention more urgently; this is about the most important interests of the State, and about a sure method of increasing the population «. ${ }^{3}$ For the Napoleonic government, the vaccine would accomplish with no struggle what the Revolution had attempted in storm and fury: the regeneration of man. ${ }^{4}$ However, despite the spectacular scale of the stakes, there was no general compulsion for vaccination in France before 1902. It was Napoléon himself who rejected the urgent appeals of the vaccinators. ${ }^{5}$ For the emperor, before being subjected to a grand project of biological amelioration, French society was to be reorganised on the authority of the pater familias (the head of the family, the keystone of the newly established Civil Code), an authority which the imperial regime did not wish to violate as it was a reflection of its own power. Compulsory vaccination belonged to the revolutionary projects of decreasing paternalist power which the Napoleonic Code, contemporaneous with the vaccine, intended rather to restore. ${ }^{6}$ In 1808 , the Minister of the Interior, Joseph Fouché, countered a report from the vaccinators: »the coercive measures which they propose are not at all authorised by law and gentleness and persuasion are the most efficient means of making the new inoculation a success «. ${ }^{7}$ But how does one govern with gentleness and persuasion? What was "soft power « under the Empire?

Vaccination is a classic historical subject. Historians have studied its demographic consequences, ${ }^{8}$ the organisation of vaccination campaigns, ${ }^{9}$ the English anti-vaccination movement, ${ }^{1}$ and the modalities of the vaccine's global diffusion. ${ }^{11}$ The purpose of this article is different: it refuses to consider the vaccine as an essence transmitted by neutral vectors. It proposes a "historical ontology " of the vaccine, that is, a history of the definition of its competencies, of its representation (through the clinical gaze, medical imagery and statistics) and of the production of a social consensus on this representation.In 1800 , the vaccine was not much more than a neologism. It was a mysterious entity with almost no existence (if not transmitted, it ceased to exist), no essence, and as yet rather vague characteristics. The nature of vacci- 
nation, its risks and its uncertainties fostered a fierce controversy among Parisian doctors between 1800 and 1803. Several books were published about its dangers, describing numerous accidents. But three years later, the French government officially declared that vaccination granted an unlimited protection from smallpox and was without any danger whatsoever. Posters printed by the departmental administrations stated in large print: "Citizen! Vaccine is no longer a problem; its benefits cannot be disputed «. ${ }^{12}$ This article demonstrates how the French administration succeeded in imposing the idea of a perfect vaccine. It focuses on elements which could be brushed aside as details of the vaccine story: the organisation of administrative correspondence, the censorship of medical information, the forms furnished by the administration for registering vaccinations, or the engravings of vaccine pustules. It is through these "details", these "little tools of knowledge «"13 that the proof of vaccine's perfection was administered and biopolitics exercised.

This articles relies mainly on the archives of the Comité national de vaccine, which are kept at the Académie de Médecine in Paris, in the Archives nationales and in various Archives départementales across France. This committee was founded in April 1804 by Jean-Antoine Chaptal, the powerful Minister of the Interior, so as to supervise every matter related to vaccination. It comprised sixteen renowned Parisian doctors (among them: Pinel, Hallé, Guillotin, Thouret, Corvisart) and was spearheaded by a young and active doctor, Henri-Marie Husson, who reported every week to the Minister of the Interior on the progress of vaccination in France. ${ }^{1}$ The archives of the Comité offer a fantastic window on the relationship between governance, public health, and the management of medical information. At this time and because of vaccination, a new relationship between administration and medical facts was forged. Doctors were absolutely struck by the powerful involvement of the government in medical doctrine. According to one of them, the vaccine "was the result of the perfection that the science of government has recently acquired in France». Another vaccinator praised the government for giving to the vaccine "an administrative form, and even the power of the law«. The setting up of a permanent committee on vaccination was indeed a momentous transformation in the management of expertise in
France. According to Chaptal, the issue of vaccination "must cease to be medical and become a matter for the government «. ${ }^{1}$ During the eighteenth century, inventions, new medical procedures or new machines, were appraised by temporary commissions, most often taken from the Academy of Sciences or the Royal Medical Society. Similarly, when in 1763 the Parliament of Paris asked the Faculty of Medicine to review smallpox inoculation, the latter appointed a temporary commission of twelve doctors. Compared to temporary commissions, the Comité de vaccine could capitalise knowledge and authority in the long term.

For the Comité de vaccine, the medical doctrine was the key, precisely because of the absence of legal compulsion. Most of the first promoters of vaccination had been ardent promoters of smallpox inoculation, in the last decade of the eighteenth century. Given the danger of this practice, they had relied on a probabilistic discourse: mortality statistics, they argued, demonstrated that it was reasonable to risk one's life so as to better protect it. But this vision of individuals as rational gamblers had utterly failed. Few people (thousands at most) got inoculated in France in the eighteenth century. ${ }^{16}$ The vaccinators' strategy differed on this crucial point: vaccine had to be absolutely riskless. The main job of the Comité was to establish and maintain a definition of the vaccine so as to cancel all reluctance.

"Superior Legislation «, wrote Jeremy Bentham, »leads men by silken threads, entwined round their affections, and makes them its own forever «. ${ }^{1}$ I would like to show how the vaccine of 1800 was one of these silken threads of post-revolutionary power. In establishing a new natural entity, doctors intended to govern the body not by coercion, but indirectly by orientating perceptions.

\section{Uncertainties}

In the spring of 1800, a new inoculation by the name of cowpox had begun to be talked about in Paris and the doctors had reasons to be sceptical. ${ }^{1}$ What was the nature of this pus? Was one indeed sure of inoculating true cowpox? And how even to answer such a question, as the substance imported from Britain had travelled through hundreds of bodies, which were susceptible to a variety of ailments?If, as commonly understood, the 
vaccine was not simply a kind of mild smallpox, what could it very well be? Above all, how to explain its preservative effect? It was easy enough to criticise the vaccination system on theoretical grounds. How could a local outbreak with almost no associated fever destroy the "constitutional trait « which predisposed every individual to smallpox? How to explain that a smallpox infection can occur during vaccination itself? In a strange way, the vaccine would protect from future smallpox but not from present smallpox. Opponents used the chemical analogies which were in vogue in medicine at the time to make clear the absurdity of this postponed effect: how could the vaccine be useless to neutralise smallpox when in contact with it and become efficacious when smallpox was absent from the body? Smallpox inoculation anticipated a natural phenomenon in eliciting smallpox through smallpox; to inoculate an unknown disease seemed much more reckless.

The problem with the vaccine was not only that it involved a personal risk, in the sense of inoculation comprising a risk of death, but that its potential effects on the general health of the nation were unknown. Contrary to smallpox, cowpox was rare and non-contagious. One needed therefore to transfer it from arm to arm, from the vaccine-bearing to the vaccinated, following an ever longer chain. Vaccinating thus amounted to inoculating a virus which had thrived in hundreds of bodies, which themselves could have been affected by a variety of illnesses. Because the vaccine could transmit hereditary diseases such as syphilis or scrofula, it could jeopardise the health of "all generations to come «, ${ }^{1}$ or even »the constitution of the human race «. ${ }^{2}$ By hybridising, cowpox could also create new infections: "the viruses mix together and form combined viruses which are even more alarming: they spread both by reproduction and infection. They degenerate the national temperaments «. ${ }^{2}$ The possibility of a catastrophe should have compelled a longer period of experimentation before disseminating a new virus in the population. The Prussian doctor Marcus Herz particularly emphasised the necessity of deferring the general introduction of the vaccine. The smallpox control experiments on hundreds of vaccinated people and the good health of thousands of others proved nothing. The problem was not the number of experiments but their duration: "fifty thousand tests are not enough for completing the ex- periment and one hundred thousand would not add any additional proof «. The problem was evaluating the longterm consequences of the innovation. It would be necessary first of all to stop cowpox inoculation and with careful attention observe the outcomes of vaccinated people. After ten years, the results would be communicated to the public and doctors so that they could debate. If success seemed clear, one could subject another 50.000 individuals to the same procedure. Finally, if the vaccine still maintained efficacy after one generation, it would be possible to introduce it to the entire population. This, according to Herz, was the only way to achieve the rigour appropriate to the colossal scale of the stakes: the health of the present and future generations of the European population. ${ }^{2}$

\section{Test tube bodies}

In the initial period of vaccination there was a profound transformation of the role of human experimentation in medicine. The demarcation of this change is elusive as human experimentation is not a category with clear borders: the art of clinical proof is indeed setting experimentation within a therapeutic project so as to associate it with simple observation. ${ }^{23}$ But if there is a continuum between experimental observation for a therapeutic purpose and human experimentation for a merely exploratory purpose, the trials carried out by the Comité de vaccine (henceforth Comité) ${ }^{24}$ between 1800 and 1803 were very atypical: they subjected a large number of children to trials which had no therapeutic objective. From this specific instance, medicine gained very wide latitude over the use of bodies.

In the eighteenth century, experimental subjects were either the doctors themselves or prisoners condemned to death. ${ }^{25}$ Human experimentation was hardly different from dissection because experimental bodies were legally considered already dead. Relying on the royal right to punishment, human experimentation was not a standard method of proof in medicine. With the vaccine, medicine escaped these restrictive frameworks. The number of bodies subjected to experimentation rose by orders of magnitude: it was no longer a case of a few prisoners, but of excessive quantities of bodies, of bodies abandoned by the thousands. 
In 1800 , the vaccine was a new entity. Its nature and the origin of its efficacy were completely unknown. There were also many unfortunate vaccinations. ${ }^{26}$ The vaccine was also a rare and transitory entity: its existence depended on its transmission. If the doctors did not have any more subjects to vaccinate, it disappeared. The attempts to save the pus ex vivo (in glass plates, capillary tubes, vacuumed flasks or flasks filled with nitrogen) failed. Vaccines were much more successful when made with fresh material, from arm to arm. ${ }^{27}$ Thus, to preserve and transport this precious virus, doctors had to organise chains of arm to arm vaccinations. Throughout the course of the nineteenth-century, foundling children constituted the indispensable links.Let us take an example. In October of 1800, Husson, secretary and lynchpin of the Comité, took the vaccine to Reims. He inoculated his family and friends. On returning to Paris, he declared in an optimistic article: "the fire of the vaccine keeps burning «. ${ }^{2}$ The metaphor, taken in a prehistoric sense, is judicious: the first vaccinators struggled to maintain constant chains of transmission. They were always in search of children to vaccinate in order to maintain the virus. Yet few parents were willing to surrender their children to the lancet, especially with the coming of winter. ${ }^{2}$ Therefore the doctors of Reims urgently needed to vaccinate abandoned children, which the foundling hospices administration rejected. In his private correspondence, Husson shared his doubts: "I fear that the vaccine will come to ruin in a short while «. ${ }^{30}$

The nomination of Chaptal to the Ministry of the Interior on November 7, 1800, changed the political situation of the vaccine. Pinel, whom he had met in the 1770 s on the benches of the Montpellier faculty of medicine, ${ }^{3}$ convinced him that the innovation would allow the eradication of smallpox. ${ }^{3}$ From 1801, at his order, the hospices became open to vaccinators. The balance of authority had changed. When a prefect refused access to the foundlings, the vaccinators threatened: »it would be unfortunate to be obliged to write of this matter to the Minister of the Interior who is our partner «. ${ }^{3}$ It was at this very moment that the continued existence of the vaccine was assured: until the end of the nineteenth century, foundlings were used to produce and transport the vaccine. As Yves-Marie Bercé has already emphasised, "without them nothing would have been possible «. ${ }^{34}$ An 1809 decree euphemistically designated 25 hospices for foundlings as "vaccine depots «, in order to maintain the vaccine. Even if the administrators and the nuns were often hesitant to vaccinate the vulnerable new-borns, from then on authority was transferred to a doctor chosen by the prefect for his vaccinating zeal.Maintaining the vaccine was delicate work: it was necessary to arrange the vaccinations so as to allow fresh fluid to be available on demand as well as to be able to inoculate "vaccine depot « children at various sites on the body to produce even more pus (eight per child in the Paris vaccine hospice, ${ }^{3}$ sometimes even upwards of fifty when there were not enough children). ${ }^{3}$ To extract the precious fluid, the pustules were opened and pressed several times. This procedure was done in public: in villages, the mayor, told of the vaccinators' arrival, had to accompany the non-vaccinated children to the town hall. This avoided futile travel for the vaccinator and allowed legalisation of vaccines: certificates (necessary for school registration and obtaining public funds) were often signed by the mayor. It was not the biological exploitation of misery that frightened off parents. Rather, they held the health of foundlings in suspicion: the fruits of depravity, they feared, would transmit syphilis. They demanded to inspect their bodies and preferred the pus of legitimate children. They reproached the system for being dangerous, but never for being inhuman.The hospice children also served as a testing ground: on them the vaccinators acquired the savoir-faire and experience necessary to judge good and bad vaccines. As adverse reactions on these children could be passed over in silence, the vaccinators did not risk enduring parental accusations or nourishing anti-vaccine treatises.

At the beginning, doctors who did not know anything about the vaccine needed to identify its phenomena and learn how to regularly reproduce them. The Comité established, for example, the length of time necessary to develop effective protection post-vaccination by organising smallpox control experiments on 40 children: first vaccine and smallpox were injected at the same time before the second inoculation was delayed day by day. ${ }^{37}$ Another problem: at what age could one vaccinate? The Comité operated on younger and younger children, even vaccinating premature babies. No age seemed inappropriate. Additionally, it could be possible that the protection afforded by the vaccine was only local. Therefore, smallpox was inoculated in the extremities opposite to the vaccination points. ${ }^{38}$ The vaccinators also tried to reproduce 
adverse reactions: they placed pus in the throat or nasal mucous membranes to study the respiratory complications linked to the vaccine. Similarly, to understand vaccine-related eruptions, they broke the skin and applied several drops of the vaccine pus. The subject acquired a gangrenous wound..$^{39}$ Inside the hospice, human experimentation became banal. Foundling children served as test bodies: if an infectious disease occurred after a vaccine, the children were inoculated with the pus in question to verify that it was not a case of smallpox. ${ }^{4}$ Experiments were also conducted with the goal of refuting the risk of contamination by vaccine: Alibert vaccinated the leprous, those with scrofula, and those with ringworm by passing pus from one to the other, noting no cross-contamination. Cullerier and Richerand reported on a vaccine taken from syphilitic children into healthy ones without infection. These dangerous and oft criticised experiments were conducted on only a few children. ${ }^{41}$ However, they had considerable consequences: throughout the entire century, with regards to hypothetical cases of syphilitic contamination, the doctors invoked the great experiments of the Comité at the beginning of the 1800s to exonerate the vaccine. Overall, thanks to experimentation on foundlings, the Comité explored and defined the vaccine's competencies. The philanthropic programme of a completely benign virus which could be inoculated into everyone began to become consistent.

In November 1801, the Comité organised a largescale public experiment in Paris: 102 foundling children, previously vaccinated, were inoculated. Notable personages were invited to witness the success of the experiment, that is the absence of smallpox. According to the Académie des sciences, »there resulted the most decisive experimental proof that one could ever desire «. ${ }^{4}$ The British Parliament was also very impressed: Jenner had also completed control experiments, but only on four subjects. ${ }^{4}$ The dimension of uncertainty inherent in medicine disappeared with the discourse of the crucial experiment: »it is not about determining the degree of probability of the new method, but rather its infallibility: whether or not it protects from smallpox «. ${ }^{4}$ Across all of France, the same administrative ceremony of medical proof was repeated. ${ }^{4}$ In 1803, the Comité on the vaccine won its gamble: the Minister of the Interior, the prefects, notable personages, everyone was convinced by the control experiments.
However, at the same time, many doctors remained sceptical. Firstly, even if the vaccine protected from inoculation, it was possible that it could not protect from natural smallpox. Moreover, the inoculations were given, at the latest, eighteen months after vaccination, though the chief problem was the duration of the protection. Thirdly, while the children of the hospice constituted convenient experimental material, this material was defective, as without parents, one did not know their medical histories. Their immunity could have been due not to the vaccine but to an earlier unknown case of smallpox. ${ }^{46}$ Finally, even if smallpox was an external disease, the diagnostic was not as simple as it seemed. To decide whether or not a child had smallpox was a delicate matter on which the administrators, invited to witness the proceedings, had no legitimacy to judge. Given that the goal of smallpox inoculation was indeed to avoid a general eruption and to restrict it to localised symptoms, ${ }^{4}$ the absence of general eruptions in the 102 experimental subjects was not sufficient proof. The real question was much more subtle: was there a difference in nature between the localised symptoms of a post-vaccination inoculation and the symptoms of an inoculation alone?

The smallpox control experiment, submitted to a critical perspective, lost its decisive character. It was no longer sufficient to be present and to witness the experiment, but it was necessary to know how to interpret it correctly, to recognise a localised case versus a general one, to recognise the inoculation symptoms equally on individuals who had smallpox and those who had not. ${ }^{48}$ There is a corollary: as the test was more convincing to those ignorant of the complex symptomology of pustular diseases, the administrators found the control experiments especially persuasive.With this controversy, the competencies which the philanthropists attributed to the new virus were translated into more ambiguous terms. The proposition "the vaccine protects from smallpox" became "there is no smallpox development manifest at the incisions «, which itself was translated into "there is a difference of nature between the development of smallpox inoculation and of post-vaccination smallpox inoculation«. It was in order to qualify this difference that the vaccinators took up the pioneering project of mapping the variable and contested world of pustular eruptions. 


\section{The graphic nature of the power of the vaccine}

Everything started with a particularly tortuous note at the bottom of page 7 of Jenner's Inquiry. ${ }^{49}$ Before presenting the cases supporting his theory, the cases of farmers who had cowpox and were thus protected from smallpox, Jenner referred to a mysterious cow disease which was very similar to cowpox and transmissible to humans, but which did not immunise against smallpox. ${ }^{50}$ The distinction between cowpox and spurious cowpox gave a degree of freedom to Jenner's theory: the many cases of smallpox after vaccination reported by his colleagues could now be attributed to a "false vaccine« rather than harming the reputation of the true one. ${ }^{51}$ The notion of a false vaccine, at the beginning sufficiently marginal to be relegated to a footnote, rapidly became the central cog of vaccination theory. For its opponents, this was a crude subterfuge to make the vaccine irrefutable. It is on this very question that the new clinical gaze analysed by Michel Foucault played a critical role. The central Comité established an extraordinarily precise symptomology of the typical pustule of the true vaccine and discarded all that did not correspond to this definition. The point is not to say that the Comité or Jenner was cheating: there were certainly vaccines which did not produce the expected effect. The stakes were rather to define the criteria of success for the vaccine and, through these, the persons who could legitimately judge them.

In treatises on the vaccine from the beginning of the century, dozens of pages were devoted to extraordinarily detailed descriptions of the pustule: its size, its form, its colours, its consistency, its silhouette, its induration, its elasticity, and all these at different stages of its existence. This minutia was novel. In the eighteenth century, symptoms were considered as simple signs of the disease of which the essence remained inaccessible. Inoculation, in its very principle, rested on the disjunction between essence and symptoms: one could hope to have smallpox without eruptions, the disease without its symptoms. The novelty of the clinical gaze hinged on erasing this separation: there was no more pathological essence, a disease was nothing more than the collection of symptoms which manifested it. ${ }^{52}$ Therefore, when the doctors of $1800 \mathrm{ob}-$ served the post-vaccine pustule, they saw the disease itself. The pustule was not the sign of the vaccine, it was the vaccine.In the eyes of trained men, the vaccine will always be defined by [the following] general characteristics: 1) the central depression, 2) the areola, 3) the subcutaneous tumour, 4) the limpidity/clarity of the fluid, 5) its deposit in recesses or isolated cells, 6) the silver tint of the pustule, and 7) finally, its very regular form. ${ }^{5}$ The clinical definition permitted a justification of the vaccine's failures: if a pustule did not unfold according to this succession of phenomena, it was not a true vaccine and thus could not protect from smallpox. The clinical definition also explained the Comités refusal for revaccination until the 1840s: as it was difficult to obtain a "true vaccine " pustule at the time of a second vaccination, and as this pustule was the condition for the protective effect, the Comité insisted on the importance of a good first vaccine and rejected the anomalous pustules produced by secondary vaccinations.

The problem with the clinical definition was that it rested on nuances which were difficult to articulate. The palette in vaccine treatises is particularly rich: "clear red", "greyish white«, "opalescent colour", "rose tint «, "light purple tint «, "yellow-tinged «, "a tan colour like barley sugar", "mahogany wood «, and so forth. ${ }^{5}$ Colours, reduced to the rank of secondary qualities by natural philosophy, the botanical system and medical nosology, ${ }^{5}$ became, in the clinical description, the essential characteristic of the most significant disease of the new century. Husson, for example, insisted on the "bright cherry red of the inflamed areola, glazed with white «; 5 the 1803 report made the silver colour of the bulge around the areola the determining criterion of the true vaccine and compared its colour "to that of a fingernail pressed at the tip $\aleph^{57}$.

It is here that the second great innovation of the vaccinators came about: the graphic definition of the vaccine. From the beginning of its work, the Comité addressed itself to Anicet Lemonnier, painter and illustrator for the École de medicine. ${ }^{5}$ The 1803 report emphasised his presence:

Many occasions were offered to him to follow the vaccine in all of its nuances, varieties, degenerations; he availed himself of his skills in drawing and painting to convey images faithful to the vaccine's development in men and cows [...] and in its various stages of true or false vaccine. ${ }^{59}$ 
The rapid progress of the representations of the pustule shows that the vaccinators were well on their way to inventing a new graphic code.

The sociology of science has shown how scientific images, by selecting what is to be perceived, augment the visibility of nature and define what becomes knowable. ${ }^{60}$ In 1800 , the simultaneous presence of the painter and the clinician around the same vaccine pustules contributed to a stabilisation of phenomena, a normalisation of observations and the establishment of the pustule as a docile object of knowledge. The vaccinators' rich palette arose from their collaboration with painters. The nosology of the vaccine which transformed nuances into essences thrived on the richness of the pictorial lexicon. In choosing colours, shades, reliefs and textures, the painter and clinician together defined the characteristics of the true vaccine: the doctor guided the gaze of the painter and controlled his brush, the painter stabilised reality and helped the clinician to name it. Clinical descriptions and pathological images reciprocally formed each other: the clinical and graphic description of the true vaccine was constructed through lexical transfers from painting to the clinic and in a strange cognitive space formed by the clinical experience restructured by the image.

In studying the composition and use of these images, we enter into the heart of medical power where it is exercised in silence, at the point where language is not yet imposed on things. The vaccine image is not a copy of nature, but an interpretation after nature; it is not a still life rendering the specific appearance of a pustule, but a typi-
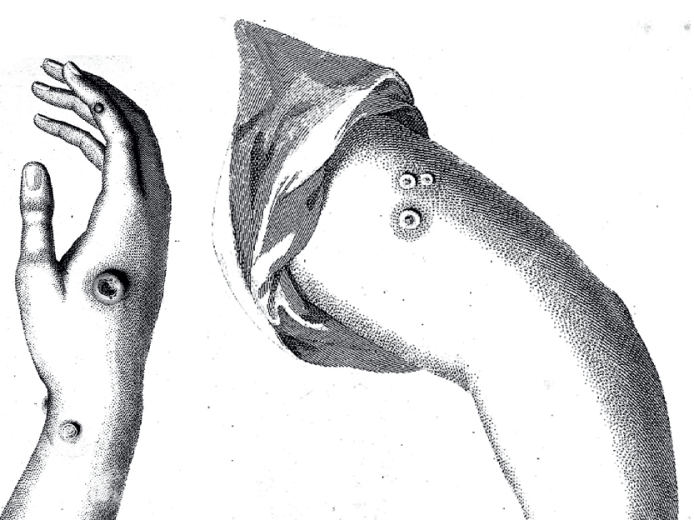

Figure 1 - Edward Jenner: An Inquiry into the Causes and Effects of the Variolae Vaccinae, London, 1798. cal image accentuating the characteristics of the vaccine. The doctors corrected the artist when he reproduced insignificant details. The typical vaccine is thus understood as the best specimen, one that magnifies the regularities discovered thanks to clinical experience. Dr Fournier did not hesitate to choose according to aesthetic criteria the model he had engraved: "among the more than four hundred individuals of both sexes whom I have vaccinated, a six-year-old girl [...] of blossomed beauty [...] gave me [...] the most beautiful areola which I have ever seen «. ${ }^{61}$

The details deemed essential were described with an extraordinary precision. The images reproduced above deployed an armada of details. The colours were essential. Time was as well. Hence the importance of a temporal representation of the vaccine: it was insufficient to obtain a pimple which vaguely resembled the represented pustule, it was necessary that the pustule exhibit the same succession of phenomena in time. Note also that the cross-sectional representation of the pustule (fig. 6) allowed a definition of the vaccine according to the sense of touch. The clinical experience, in proposing the visibility of the pathological and in refining the medical gaze, permitted the vaccinators to transform detail into a particular sign, in a slip of nature which betrayed itself in the fold of a pustule. This culture of scientific representation which organised the use of detail, and made the ideal subject and fidelity to nature equivalent, produced an effect of power. In purifying, summarising and amplifying certain vaccine phenomena, it transformed different vaccines into as many varieties of false, anomalous, weak and irregular vaccines.

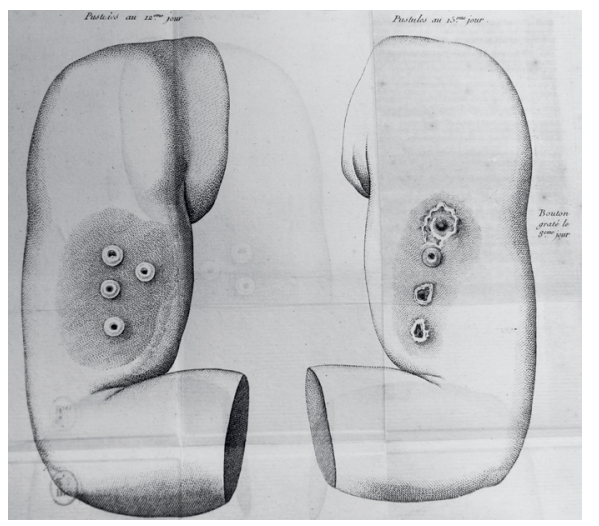

Figure 2 - Hugues-Félix Ranque: Théorie et pratique de l'inoculation de la vaccine, Paris, Mequignon, 1801. 
The nosological work around vaccine was refined with time. For example, Pierre-François Rayer proposed, in the dermatological reference atlas of 1830-1840, the category of "vacciniola" (vaccinelle) in addition to that of the false vaccine. With the vacciniola, the virus had infected and the pustule presented the characteristic signs (the central depression in particular), but the pustule passed through the different stages of maturation much more rapidly than with the true vaccine. And, of course, it did not protect against smallpox. ${ }^{62}$

The same nosological barricading occurred downstream, with respect to smallpox. Chickenpox had been distinguished since the eighteenth century from smallpox, which in itself presented more or less serious varieties. From the 1810s, at the time of smallpox epidemics, many of those vaccinated developed symptoms similar to those of smallpox although attenuated. For the honour of the vaccine, these illnesses could not be smallpox. It was then necessary to invent new diseases similar to smallpox but never before diagnosed. Most often, doctors invoked new, particularly severe, varieties of chickenpox. Rayer's dermatological atlas thus makes subtle distinctions between varioloid and chickenpox, between umbilical, conical, globular or vesicular chickenpox, and between vaccine, vacciniola and false vaccine. The complexification of the field of pustular diseases in the 1830s was the direct results of bitter struggles about the vaccine and its protective virtues.

The vaccinators achieved a medical and methodological stroke whose historical significance cannot be overestimated. Never before had medicine defined a disease by its image. ${ }^{63}$ The nosological revolution at the end of the eighteenth century (Boissier de Sauvages, Cullen, Pinel) was accomplished without images, as the transitory reality of an illness, varying case by case, circulating even within the body and possibly among different sites, prevented any graphical definition. In 1800, no one was prepared to accept the hypothesis that a disease could be recognised by an ensemble of traits and range of colours. Georges Cuvier, who underlined the novelty of graphic nosology offered by the vaccinators, explained its limits:

... as no one is ill in precisely the same way as another, we cannot but give individualised portraits of our infirmities, while in regular beings, the individual represents the species. ${ }^{64}$

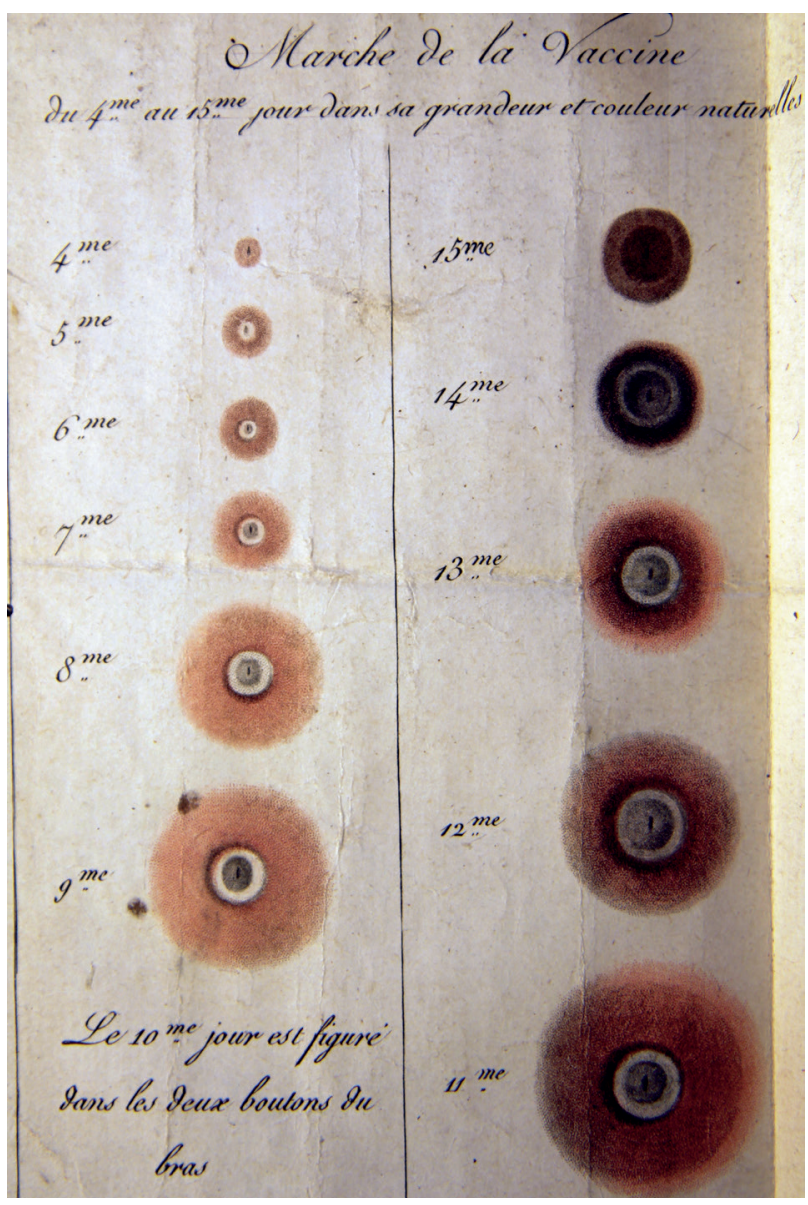

Figure 3 - Henri-Marie Husson: Recherches historiques et médicales sur la vaccine, Paris, Gabon, 1801.

As for Dr Goetz, he ridiculed the vaccinators aping the botanists:Tournefort and Jussieu did not better design their knowledgeable system of plants [...] and the most well-ordered bed of the most stunning flowers does not present a more astonishing sight for the enchantment of the eye than the grey, the white, the red and the charming pinks of the vaccine pimples. ${ }^{65}$

What happened with the vaccine in 1800 was the possibility to graphically define a typical disease. In 1805, the first dermatological atlas appeared (by Robert Willan and Jean-Louis d'Alibert), then in the 1830s, the first atlas of pathological anatomy. The visual culture of nineteenth-century medicine inherited the nosological enterprise of the first vaccinators. 


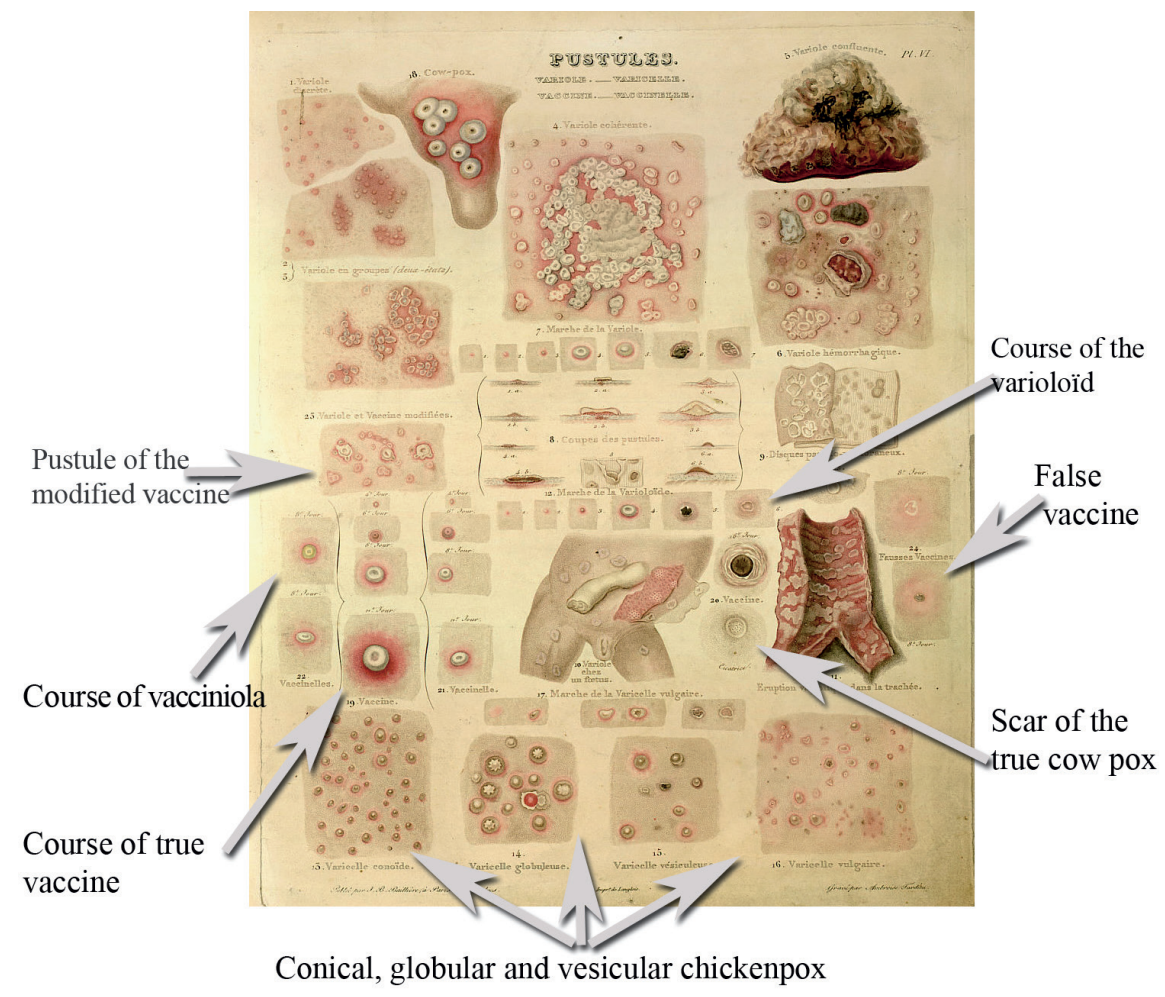

Figure 4 - Pierre-François Rayer: Traité théorique et pratique des maladies de la peau, Atlas, 1835.

\section{Statistics and agnotology ${ }^{6}$}

In France, the public controversy around vaccine immediately ceased in 1804 when the government endorsed the theory of a perfectly benign vaccine. The Minister of the Interior ordered that every article on the vaccine had to be approved by the Comité before publication. ${ }^{67}$ The philanthropic Comité de vaccine became a "Comité central " placed under the authority of the Ministry of the Interior. Its members, the most influential Parisian doctors (Thouret, director of the École de santé, Pinel, chief doctor of the Bicêtre hospital, Mongenot, chief doctor of the children's hospice, etc.), were now paid by the administration. Committees were also established in each department to correspond with the central Comité. In 1804, a doctor said of the vaccine that it was "the result of the perfection of the science of government «. ${ }^{68}$

The important thing that administration did for vaccine was to reorganise the circulation of medical information. The circular of 1804 which established the vaccine service in France had a double purpose: to make return, to record the vaccination results in order to statistically corroborate the protective nature of the vaccine. According to Chaptal, »in reporting every year the decreasing number of people afflicted with smallpox, and the lower proportion of its victims in the mortality tables, we will achieve general acceptance $«{ }^{6}$ Statistics are not only the sensorium of biopower, but its main form of communication to the people. On the one hand, the statistics divulged the risk of smallpox: the prefects had to publicise the names of smallpox victims, so as to subject to public indictment the parents who did not have their children vaccinated. ${ }^{7}$ On the other hand, in undertaking an exhaustive inventory of all the vaccines, the statistical project generated suitable results.

Let us look into the concrete ways of producing vaccination statistics. The administration obliged the vaccinators to complete tables with six columns: the vaccine number, the date, name of the patient, age, residence and "observations". Accustomed to writing up cases in notebooks, the vaccinators now had to record their observations in a narrow column. The options were to either leave it entirely empty - which they did for the 
most part - or to summarise the results of their actions in a few sentences. It is in these notes written in constricted characters that the dangers of the vaccine can be glimpsed. One vaccinator from the Hautes-Alpes notes, satisfied: "All the children vaccinated in 1806 only had a few small ulcers and dry patches [...]«. The dermatological waxes of the Saint-Louis hospital indicate the severity of these post-vaccination illnesses, considered very banal in the nineteenth century.

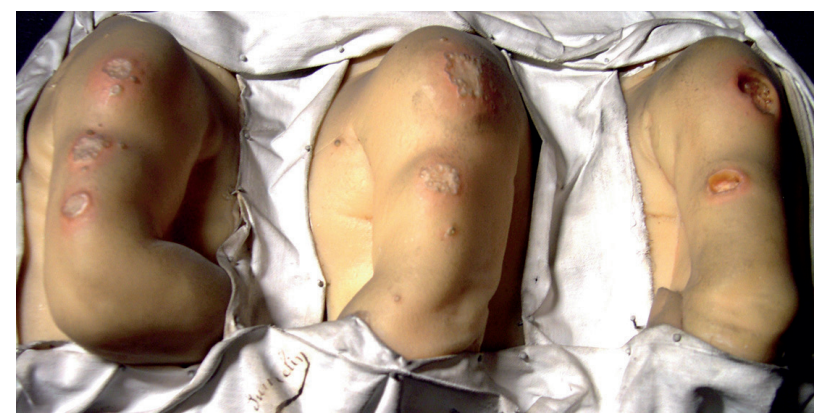

Figure 5 - Vaccine ulcers (around 1880), waxes from the Saint-Louis hospital.

In 1806, Coste, a surgeon at Montauban, vaccinated no more than twelve people, but reported two miliary eruptions which lasted twenty-one days. For Gasquet's count of twenty people vaccinated, there was one scrofulous tumour and one miliary eruption. ${ }^{71}$ In the Orne, one vaccinator counted eight general eruptions among 276 people vaccinated. ${ }^{72}$ Dr Taulin, from Saint-Dizier, supplied a table comprising 157 vaccinated people, the "observations « column telling of eight complications of which two were fatal. ${ }^{7}$ In 1812 at Nantes, Dr Valteau vaccinated 32 newborns at the hospice for foundlings; 22 were deceased within a month following the vaccination $^{74}$.

Ignorance, like knowledge, is constructed. With regard to vaccination risks, ignorance was produced by a pyramidal system of information gathering, organised in multiple levels: town councils, departmental committees and the central Comité, all of which amounted to as many filters of negative news. Complications (various, sometimes dangerous, eruptions), reported in a literary manner in the "observations" column, were only rarely taken up by higher echelons which, having quantification as their objective, preferred numerical information. Because the vaccine was supposed to be completely benign, the health officer or the doctor who met with a complication could fear that he would be marked for bad practice. For example, two vaccinators passing through the Alps in 1820 produced hundreds of eruptive diseases. For 600 people vaccinated, there were 40 deaths. The departmental vaccinators accused the health officers of confusing or mixing the vaccine pus and the smallpox pus. ${ }^{7}$ Administration of the vaccine, not very remunerative, was generally performed by simple health officers. They received meagre allowances from the departmental administration, corresponding to the number of completed vaccinations. Reporting accidents meant taking the risk of being labelled an "anti-vaccinator " and of being exposed to the reproaches of the vaccine committees and the prefects. It was much more practical to keep one's observations under wraps and one's scruples to oneself. Statistics also had a moral function: the responsibility to keep quiet about accidents for the greater good of the nation. The work of refuting parental pleas and of clinically exonerating the vaccine spread throughout the entire vaccine system. Each level had its own share of complications, misgivings and indignity.

At the summit of the system, statistics produced an extremely convenient argument: vaccinations, on the whole, and as reported by the abundant tables with constantly empty columns, were absolutely without danger. A scant number of accident reports happened to pass the successive obstacles of auto-censorship, censorship and the meticulous verification by the Comité. In short the few adverse effects or cases of smallpox after vaccine which remained inexplicable and were forced on the conscience of the central Comité were balanced with the hundreds of thousands of problem-free vaccinations. And, of course, these cases did not have significant weight and did not at any rate succeed in imposing a redefinition of the perfectly benign and perfectly protective vaccine.

\section{The powerlessness of the anti-vaccinators}

From the 1880s, the arm-to-arm method of vaccination was abandoned. Vaccines were produced on heifers 
rather than humans. In the "vaccine institutes«, strict procedures limited the risk of contagion: disinfection of the lymph, microscopic examination, cultures and analysis of bacterial flora, refrigerated conservation, and test inoculation into rabbits and then a few children before general distribution of the vaccine pulp. ${ }^{7}$ The vaccine became a potentially dangerous substance, controlled by the latest bacteriological techniques. How to explain this redefinition of the vaccine? How were those questions re-opened which the Comité seemed to have settled so well?

Throughout the course of the century, the public's suspicion with regards to the vaccine endured and even intensified. The fear of bodily pollution, blood adulteration and hereditary contamination explains the hesitancy. Opposite to hygienic precepts grounded in a strict separation between cleanliness and dirt, the vaccine seemed to dissolve the reassuring borders between one's own body and the bodies of others, between the healthy and the pathological, and even between the human and the animal. ${ }^{7}$ Despite this favourable terrain, the anti-vaccine doctors did not succeed in modifying the official medical doctrine. The problem was that they chose to place the discussion at the most general level possible. In France in the 1850s, they did not try to collate and publish the vaccine-related accidents, but instead tried to show the link between the vaccine and the "degeneration" of the population. ${ }^{78}$ They addressed themselves less to parents (although many of these were hesitant about the vaccine) than to the government, which they warned against the blinkers of the Comité. Their argument (which was brushed aside by the Academy of Medecine and by the statistician Louis-Adolphe Bertillon ${ }^{79}$ ) was almost exclusively statistical: they exhibited (weak) correlations between vaccination and the multiplication of certain pathologies (chiefly typhoid but also scrofula, tuberculosis, cachexia, scoliosis, etc.). These correlations, determined from incomplete or incoherent series, did not stand up to close critique. The anti-vaccinators did not discuss or analyse the statistical aggregates produced by the vaccine Comité but contented themselves with correlating them with other aggregates produced by hygienists from the 1850s (dimensions of conscripts, birth rate, disease statistics, etc.). In wanting to show too much, the French anti-vaccinators did not convince anyone: they created much confusion and little mobilisation.
In Great Britain, the situation was very different. Because of the vaccination act of 1853, under which parents refusing to vaccinate their children were sent to jail, the anti-vaccine movement grew to a far more considerable size than in France. Nadja Durbach has studied its intellectual and social milieu. It was anchored in industrial towns: Manchester, Sheffield, Liverpool and Leicester (where $90 \%$ of parents refused vaccination in the 1870s). ${ }^{8}$ It fit into a larger rejection of medical management of poverty: criticism of the poor law guardians who were responsible for verifying vaccinations, the role of the doctor in workhouses, fear of the dissection of the poor (the Anatomy Act of 1832 authorising the dissection of unclaimed bodies), and the support of trade unions which refused vaccination in the factory. One also counts amongst the anti-vaccine campaigners members of the bourgeoisie who were concerned about the state's hold on medicine, contrary to the ideology of "self-help", and about the degeneration of the purity of family bloodlines, dear to Victorians. Women constituted the spearhead of the militant anti-vaccine movement, with important overlaps with the struggles for suffrage and against vivisection. In the 1870s, the movement to repeal compulsory vaccination counted almost 200 local chapters and tens of thousands of members. It was capable of mobilising crowds: in 1885, 80.000 people demonstrated in the streets of Leicester to the sounds of fanfare and burned an effigy of Jenner. The anti-vaccination leagues organised public meetings, distributed tracts, and occupied squares and markets. Posters showed appalling vaccination accidents, arms eaten away by ulcers and gangrene.

Thanks to the network of local anti-vaccination leagues, the anti-vaccine campaigners were able to organise a substantial collection of contamination accounts. Three periodicals (the Antivaccinator, the National Anti-Compulsory Vaccination Reporter and the Vaccination Inquirer) published numerous very detailed cases, based on meticulous counter-investigations. For example, in 1882, nine children died after vaccination taking place in the Norwich public centre for vaccination. The vaccine chain was carefully studied by the London organisation for the abolition of compulsory vaccination. Its conclusion was that there was no contaminated vaccine or unhealthy vaccine-bearers. 


\section{Business and syphilology: the late recognition of vaccine contaminations (1865)}

In France, the first recognition of the problem of vaccine contamination came from doctors who simply wanted to make a profit from innovation. To accomplish this, they had to create a market outside of the free vaccine offered by the Comité and the administration. They used parents' anxieties about the health of child vaccine-bearers to promote their vaccine as more pure and more reliable. The first experiments with a bovine vaccine were linked to the demands of the upper class. In Paris in 1803, the Comité resorted to using cows to satisfy wealthy patients ${ }^{81}$. At the same time in Naples, doctors Galbiati and Troja decided to abandon the human vaccine after witnessing contaminations. Syphilis seemed to them to be the principal danger: the vaccine-bearing newborns could seem perfectly healthy but still be latent carriers of a disease.

In the same way, in Paris at the end of the 1820s, Dr James raised a considerable amount of funding and organised a "Société nationale de vaccine" with the aim of promoting the heifer vaccine. In the eyes of the Académie de medicine, James's fault was that, in promoting his animal vaccine, he discredited the human (and free) one. He was excluded from the Parisian medical elite, struck from the lists of the Académie and, after his death in 1850, his enterprise rapidly declined.

The decisive re-questioning as to whether the vaccine was innocuous curiously came from the field of syphilology. It was the syphilologists, disputing over the transmission modes of the disease, who were to become interested in the vaccine to transform it into an argument in their controversy.

The controversy over the "syphilitic vaccine" of 1865 took root in the permanent conflict, dating from the 1850s, between the two French schools of venereology: the school of the Midi hospital in Paris, directed by Philippe Ricord (who was indeed a world authority in the subject), and the school of the Antiquaille hospital in Lyon, directed by Joseph Rollet. The debate was principally focused on whether or not the symptoms of the secondary phase of syphilis were contagious, ${ }^{8}$ with contagiousness defended by Rollet and rejected by Ricord. It was a problem of great hygienic, judicial and even social importance. The clinical observations which seemed to demonstrate the contagiousness of secondary symptoms (of the mouth in particular) provoked immense anxiety. A whole collection of intimate, fraternal (the beer mug that passes from lips to lips in a tavern) or artisanal gestures (glassmakers who share their blowpipes in particular) suddenly became dangerous. ${ }^{83}$ The real or supposed contamination from secondary syphilis symptoms instigated numerous trials. For example, nurses accused babies of having contaminated them and vice versa. The doctors called in as experts were entangled in the uncertainties of syphilologic doctrines. ${ }^{84}$

Thus, in 1859, the government asked for the advice of the Académie de médecine on the contagiousness of secondary symptoms. Ricord thought that he had sufficiently shown the impossibility of contagion in carrying out hundreds of inoculations of secondary symptoms on already syphilitic patients, all giving negative results. But because he refused to experiment on healthy patients, he left open the possibility of secondary symptoms that were contagious for non-syphilitic patients.

The Lyonnais school was less scrupulous. In 1858, two interns from Antiquaille inoculated the pus of secondary symptoms on healthy subjects. The medical press was very critical towards the cynicism of these experiments, which ended in a lawsuit and a conviction. In a new and interesting manner, the prosecution insisted on the necessity of obtaining the consent of an experimental subject, and in the end absence of consent was made an exacerbating fact in the grounds for judgment. ${ }^{85}$

For the Lyonnais school, this trial closed the possibilities for direct experimental proof. Rollet and Alexandre Viennois, a young intern, then chose to study the rumours that syphilis had been in several cases transmitted by vaccine. They meticulously compiled all the relevant adverse outcomes of vaccination reported in the European medical literature since 1800. The sudden entrance of vaccine-caused syphilis onto the Parisian medical scene was not then due to a new and spectacular case of contamination. In France, the question had appeared episodically since the beginnings of the innovation. One of the most discussed cases of transmission in 1865 (an Italian one) went back to 1822 and was summarised in Rayer's great dermatological treaty, which was obligatory reading for all medical students! ${ }^{8}$ In June 1860 Viennois published a long article in the Archives 
générales de medicine cataloguing around twenty vaccination instances (mostly Italian) which caused nearly 200 syphilis contaminations and around 50 deaths. ${ }^{8}$ The effect of such a synopsis is striking.

The final stage took place at the Académie de médecine in November 1864. Jean Depaul, professor of obstetrics at the faculty in Paris and the newly appointed director of the vaccine service at the Académie, proposed to send the minister a report warning of the syphilis transmission risk. The discussion of this report occupied the Académie from November 1864 to March 1865. These debates are important, as the doctors were negotiating what should be the import of rare facts: what to do with sporadic cases which disproved a rule accepted by the community? Depaul proposed nothing less than to change the epistemology of medicine. In his own terms, it was necessary to move from a system of "dissection of facts» to a "system of mutual assistance«. It was certainly possible, following Bousquet and Ricord, to show the inconclusive character of vaccine contaminations taken one by one, the insufficiency of the given proofs and the alternative interpretations that one could give. But this way of reasoning was not current anymore in the face of the immense responsibility carried by medicine in the 1860s: when one studies phenomena which have a weak relation of causality, the exceptional case is no longer an anomaly, an artefact which disappears in the great whole, but a precious clue that one must protect.

In proposing his account, Depaul's purpose was also to launch the case for animal vaccination championed by his friends, the Lyonnais doctors Chambon and Lanoix. In 1864, Chambon travelled to Naples to buy a vaccine-bearing heifer and to learn the production techniques for a bovine vaccine. On his return, he set up a small business consisting in a vaccine production stable, and tried, following the example of Dr James in the 1830s, to sell a supposedly less dangerous heifer vaccine. Bousquet continued to criticise this initiative which was going "to turn the population away from the arm-to-arm vaccine, without the ability to replace it [...]. Everyone will want the heifer vaccine, no one will have it«. Until the end of the 1880 s, animal vaccination was indeed expensive, as it was necessary to organise the transportation of the heifer (capillary tubes did not preserve the vaccine well). The animal vaccine was mainly of interest to the high bourgeoisie of large cities (Paris, Lyon, Bordeaux, Montpelli- er), where the first private vaccine production institutes were founded. In 1865, Lanoix charged 150 francs to vaccinate a well-off family and was criticised by his colleagues for this mercantile endeavour. ${ }^{8}$ In any case, the debate of 1865 at the Académie de médecine resulted in placing risk at the heart of discussions about the vaccine. The contamination affairs became legitimate subjects of study, eliciting reports, articles and theses. ${ }^{8}$ They were reported with much more diligence, as they allowed the advantages of the private vaccine production institutes to be highlighted.

\section{Conclusion}

The idea of soft power was the great liberal utopia of the end of the eighteenth century: for the Enlightenment philosophes, the good sovereign is one who does not oppress his people, who in giving free reign to his subjects' inclinations, increases his kingdom's population and riches and thus his own power. Gentleness in power is not synonymous with disobedience, because it raises gentle subjects: according to Montesquieu, »eight days in prison, or a light fine, are as striking to the sensibilities of a European raised in a country of gentleness, as the loss of an arm intimidates the Asian $« .{ }^{9}$ A gentle government develops more sensitive and thus more easily governable subjects. From here came the new objective of power in liberal thought: to no longer act by checking the body, but to direct intellects by the manifestation of reason. As Paul-Henri d'Holbach put forward, to govern with gentleness consists in "leading the weak spirits to reason, of which they are ignorant «, and thus allows a ruler to command "reasonable, meek and fond subjects.${ }^{9}$ Condorcet also insisted on the importance of the sciences, statistics in this case, for the post-revolutionary order: "when a revolution is finished [...] it is necessary to attach men to reason by precise ideas and the rigour of proofs « ${ }^{9}$ Soft power therefore had as a counterpart a powerful investment of the government in the domain of reason, proof and truth. In order to immunise the population, the vaccine had to be immunised from criticism. Hence the political function of clinical experience, medical imagery and statistics: they permitted to establish the definition of the vaccine as a perfectly benign virus protecting from smallpox forever by bringing into play the metaphysical 
distinction between essence and accident. Thanks to expertise the vaccine was not simply defined as the sum of its effects on a collection of bodies (which the inoculators of the eighteenth century had proposed), but by a subset of its effects which, presenting a greater coherence (as established by clinical experience and statistics), constituted something like its essence. If the vaccinators were able to maintain this simulacrum, it was because the State put its power of censorship at their disposition, as well as the bodies of foundling children as a testing ground. Knowledge was only capable of transforming the world as it was collaborating in step with already active political projects.From the 1820s, the vaccine traversed a long crisis. For lack of booster vaccines (1840) and an- imal production of vaccines (1880), cases of post-vaccination smallpox and vaccine contaminations multiplied. It would be easy to cast ridicule upon the vaccinators who vilified "the popular prejudices«, prejudices which became precautions the next generation of vaccinators would take. But the history of the vaccine has further meanings. The Comite played the role it was assigned, the role of a screen capturing bad news and projecting a theatre of comforting shadows. In sum, it permitted politicians and individuals to free themselves from the moral weight of decision-making. Expertise, in its capacity to define and maintain the vaccine virus as an entity lacking surprise and danger, as a simple technique with no moral consequence, separated science and politics for good. 
Journal du soir $n^{\circ} 1025$ (25 Ventôse, year IX). • Journal de médecine, chirurgie, pharmacie 1 (1800); 2 (1801). • Recueil périodique de la société de médecine de Paris 10 (year IX). • Recueil périodique de la société de médecine de Paris, vol. II, 1801. • Rapport du Comité central de vaccine, Paris 1803. A R N O L D , David: Colonizing the Body. State Medicine and Epidemic Disease in Nineteenth Century India, Berkeley 1993. B A E C Q U E , Antoine de: Le corps de I'histoire. Métaphores et politique 1770-1800, Paris 1993. B A L D W I N , Peter: Contagion and the State, Cambridge 1999. B A S H F O R D , Alison: "Foreign Bodies. Vaccination, Contagion and Colonialism in the Nineteenth Century «, in: Alison Bashford, Claire Hooker (eds.), Contagion. Historical and Cultural Studies, London, New York 2001, p. 39-60. B A X B Y, Derrick: »The Genesis of Edward Jenner's Inquiry of 1798. A Comparison of the Two Unpublished Manuscripts and the Published Version«, in: Medical History 29 (1985), p. 193-199. B A Y A R D , Armand: Influence de la vaccine sur la population ou de la gastro-entérite varioleuse avant et depuis la vaccine, Paris 1855. B EALE, Norman / BEALE, Elaine: "The Ingen Housz-Jenner Correspondence Revisited«, in: Medical History 49 (2005), p. 79-98. B E C K E R, Peter / C L A R K, William: „Introduction«, in: Peter Becker, William Clark (eds.), Little Tools of Knowledge. Historical Essays on Academic and Bureaucratic Practices, Ann Arbor 2001, p. 1-34. B E L L , David A.: The first total war, Napoléon's Europe and the birth of warfare as we know it, Boston 2007. B E N T H A M , Jeremy: „Essays on the subject of the poor laws«, in: Michael Quinn (ed.), The Collected Works of Jeremy Bentham. Rights, Representation, and Reform: Writings on the Poor Laws, vol. 1, Oxford 2001. p. 3-65. B E R C É, Yves-Marie: Le chaudron et la lancette, Paris 1984. B E R T I L L O N, Louis-Adolphe: Conclusions statistiques contre les détracteurs de la vaccine, précédées d'un essai sur la méthode statistique appliquée à l'étude de l'homme, Paris 1857. B O I S S I ER D E S A U V A G ES, François: Nosologie méthodique, vol. 1, Lyon 1772. B O N A H , Christian: L'expérimentation humaine. Discours et pratiques en France 1900-1940, Paris 2007. B O U C A U D, Charles-Victor: Inoculation d'accidents secondaires syphilitiques, Lyon 1860.Bourdais, Eugène, Sur les accidents graves qui ont suivi la vaccination de 130 enfants dans les environs d'Auray, Paris 1870. B O U S Q UET, Jean-Baptiste: Nouveau traité de la vaccine et des eruptions varioleuses ou varioliformes, Paris 1848. B R E S S Y, Joseph: Theorie de la contagion et son application à la petite vérole, à la vaccine, à leurs inoculations et à l'hygiène, Paris 1802. B R U N T O N , Deborah: The Politics of Vaccination. Practice and Policy in England, Wales, Ireland, and Scotland 1800-1874, Rochester 2008. C A R N O T, Hector: Petit traité de vaccinométrie, Paris 1857. C HAMAY O U, Grégoire: Les corps vils. Expérimenter sur les corps humains aux XVIII et XIXe siècles, Paris 2008. C H A P P O N , Pierre: Traité historique des dangers de la vaccine, suivi d'observations et de réflexions sur le rapport du Comité central de vaccine, Paris 1803. C H A P T A L, Jean-Antoine: Mes souvenirs sur Napoléon, Paris 1893. C L O S M A D E U C, Gustave: Examen critique des documents relatifs à l'epidémie de syphilis vaccinale d'Auray en 1866, Paris 1870. C O L L I N S , Harry: Changing Order. Replication and Induction in Scientific Practice, Chicago, London 1985. C O N D O R C E T, Nicolas de: „Tableau général de la science, qui a pour objet I'application du calcul aux sciences politiques et morales«, in: Journal d'instruction sociale 1 (1793), p. 105-128. C O R B I N , Alain: "La grande peur de la syphilis«, in: Jean Pierre Bardet et al. (eds.), Peurs et terreurs face à la contagion. Choléra, tuberculose, syphilis XIX ${ }^{\mathrm{e}}-\mathrm{XX}^{\mathrm{e}}$ siècles, Paris 1988, p. 328-348. C U V I E R, Georges: Rapport historique sur les progrès des sciences naturelles depuis 1789 et sur leur état actuel, Paris 1810. D A R M O N , Pierre: La longue traque de la variole, Paris 1985. D E G I V E, Alphonse: L'office vaccinogène central de l'État, Bruxelles 1913. D E L A L O U B I E, P.-L.: Essai sur l'emploi du fluide vaccin pris sur une personne atteinte de maladie ou de vice héréditaire, ou d'affection quelconque. Ce fluide peut-il être nuisible ou sans danger? Thesis from the Faculté de médecine de Paris, 1805. DELUMEAU, Jean / ROCHE, Daniel: Histoire des pères et de la paternité, Paris 1990. D R A C O B LY, Alex: "Ethics and Experimentation on Human Subjects in Mid-nineteenth-century France. The Story of the 1859 Syphilis Experiments«, in: Bulletin of the History of Medicine 77 (2003), p. 332-366. D R O U E T , Antoine: Instituts vaccinogènes et variole. Études statistiques portant sur la ville de Lyon, Lyon 1897. D U H E M , Pierre: La théorie physique, Paris 1906. D U R B A C H, Nadja: Bodily Matters. The Anti-Vaccination Movement in England 1853-1907, Durham 2005. F A U R E, Olivier: "La vaccination dans la région Lyonnaise au début du XIXe siècle: résistances ou revendications populaires«, in: Cahiers d'histoire 29 (1984), p. 191-209. F E N E T, Pierre-Antoine: Recueil complet des travaux préparatoires du Code civil, $\mathrm{n}^{\circ}$ 51, vol. 10, Paris 1927. F O U C A U L T, Michel: Naissance de la clinique. Une archéologie du savoir médical, Paris 1963. • Les mots et les choses. Une archéologie des sciences humaines, Paris 1966. F O U R N I E R, François: Essai historique et pratique sur l'inoculation de la vaccine, Brussels 1802. F R A S E R, Stuart M.: "Leicester and Smallpox: the Leicester Method", in: Medical History 24 (1980), p. 315-332. F R E S S O Z, JeanBaptiste: "Petite histoire philosophique du risque et de l'expertise à propos de l'inoculation et de la vaccine. 1750-1800«, in: Sezin Topçu, Cecile Cuny, Kathia Serrano-Velarde (eds.), Savoirs en débat, Paris 2008 , p. 197-225. G O E T Z , François-Ignace: Traité de la petite vérole et de I'inoculation, Paris 1798. • „Au rédacteur", in: Moniteur universel 10 Brumaire Year IX (1 November 1800). • De l'inutilité et des dangers de la vaccine, prouvé par les faits, Paris 1802. H E R Z, Marcus: "Über die Brutalimpfung und deren Vergleichung mit der humanen«, in: Journal der practischen Arzneykunde und Wundarzneykunst 12 (1801), p. 1-109. d'Holbach, Paul-Henri, Éthocratie ou le gouvernement fondé sur la morale, Amsterdam 1776. H U S S O N, Henri-Marie: Recherches historiques et médicales sur la vaccine, Paris 1801. • " "Réflexions sur la vaccine«, in: Recueil périodique de la société de médecine 10 (year IX), p. 118. • "Sur la vaccine«, in: Journal de médecine, chirurgie, pharmacie 1 (1800), p. 259-267. J E N N E R, Edward: An Inquiry into the Causes and Effects of the Variolae Vaccinae, London 1798. - The Evidence at Large as Laid before the Committee of the House of Commons, Respecting Dr Jenner's Discovery of Vaccine Inoculation, London 1805. L A N O I X, Gustave: Étude sur la vaccination animale, 1866. L A T O U R, Dominique: Réfutations de quelques préjugés sur la vaccine, 1823. LAYET, Alexandre: Traité pratique de la vaccination animale, Paris 1889. L É O N A R D, Jacques: La médecine entre savoirs et pouvoirs, Paris 1981. L Y N C H , Michael: "Discipline and the Material Form of Images: An Analysis of Scientific Visibility«, in: Social Studies of Science 15 (1985), p. 37-66. M A R K S , Harry: La médecine des preuves. Histoire et anthropologie des essais cliniques (1900-1990), Paris 1999. M O N G E N O T, Louis-Armand: De la vaccine considérée comme antidote de la petite vérole, Paris 1802 . M O N T E S Q U I E U, Charles: Lettres persanes, Amsterdam 1760. M O R E L, Bénédict Augustin: Traité des dégénérescences physiques, intellectuelles et morales de l'espèce humaine, Paris 1857. M U R A R D, Lion / Z Y L BER M A N, Patrick: L'hygiène dans la République. La santé publique ou l'utopie contrariée 1870-1918, Paris 1986. O Z O U F, Mona: "Régénération«, in: Mona Ozouf, François Furet (eds.), Dictionnaire critique de la révolution française, Paris 1988, p. 821-831. P A R F A I T , J.: Réflexions historiques et critiques sur les dangers de la variole naturelle sur les différentes méthodes de traitement sur les avantages de l'inoculation et les succès de la vaccine pour l'extinction de la variole, Paris 1804. P I C K, Daniel: Faces of Degeneration. A European Disorder (c. 1848-1918), Cambridge 1989. P O R T A L , Antoine / et al.: Rapport fait au nom de la commission nommée par la classe des sciences mathématiques et physiques, 
pour l'examen de la méthode de préserver de la petite vérole par l'inoculation de la vaccine, Paris 1803. P O R T E R, Dorothy / P O R TER, Roy: »The Politics of Prevention. Anti-vaccinationism and Public Health in Nineteenth-century England", in: Medical History 32 (1988), p. 231-252. PR O C T O R, Robert N. / S C H IE B I N GER, Londa (eds.), Agnotology. The Making and Unmaking of Ignorance, Stanford 2008. R A N Q U E, Hugues-Félix: Théorie et pratique de l'inoculation de la vaccine, Paris 1801. R A Y E R, Pierre-François: Traité théorique et pratique des maladies de la peau, vol. 1, Paris 1826. - Traité théorique et pratique des maladies de la peau, 1835. R I C H E R A N D, Anthelme: "Observations sur la vaccine», in: Journal de médecine, chirurgie, pharmacie 2 (1801), p.113-117. R U S N O C K, Andrea: »Catching Cowpox: the Early Spread of Smallpox Vaccination 1798-1810«, in: Bulletin of the History of Medicine 83 (2009), p. 17-36. S A L M A D E, Mathieu-Antoine: Instruction sur la pratique de l'inoculation de la petite vérole, Paris 1799. S K ÖLD, Peter: »From Inoculation to Vaccination: Smallpox in Sweden in the Eighteenth and Nineteenth Centuries", in: Population Studies 50 (1996), p. 247-262. TAR D IE U, Ambroise: Étude medico-légale sur les maladies produites accidentellement ou involontairement, Paris 1879. T H O R E L, Jean-Étienne: Dissertation sur les préjugés populaires qui s'opposent à l'adoption générale de la vaccine, Strasbourg 1823. V A L E N T I N, Louis: Résultats de l'inoculation de la vaccine dans les départements de la Meurthe, de la Meuse, des Vosges et du Haut-Rhin, Nancy 1802. V A U M E, Jean-Sébastien: Les dangers de la vaccine, Paris 1801. V E R D É - D E L I S L E, Henri: De la dégénérescence physique et morale de l'espèce humaine déterminée par le vaccin, Paris 1855. VE R D I E R, Jean: Tableaux analytiques et critiques de la vaccine et de la vaccination, Paris 1801. V I E N N O I S, Alexandre: "De la transmission de la syphilis par la vaccination", in: Archives générales de médecine, 5e série, 15 (1860), p. 641-671. W E I NER, Dora: "Le droit de l'homme à la santé, une belle idée devant I'assemblée constituante 1790-1791 «, in: Clio Medica 5 (1970), p. 12091223. 
1 For this "cowpox", Jenner coined the designation "variolae vaccinae». Hence the origin of the word "vaccine« which comes from the Latin »vacca«.

2 J. Parfait, Réflexions historiques et critiques sur les dangers de la variole naturelle sur les différentes méthodes de traitement sur les avantages de l'inoculation et les succès de la vaccine pour l'extinction de la variole, Paris 1804, p. 67.

3 Circular, 14th Germinal, year 12 (4 April 1804).

4 On this fundamental theme, see Mona Ozouf, "Régénération«, in: Mona Ozouf, François Furet (eds.), Dictionnaire critique de la révolution française, Paris 1988, p. 821-831; Antoine de Baecque, Le corps de l'histoire. Métaphores et politique 1770-1800, Paris 1993. On revolutionary biopolitics, see Dora Weiner, "Le droit de l'homme à la santé, une belle idée devant l'assemblée constituante 17901791 «, in: Clio Medica 5 (1970), p. 1209-1223; Jacques Léonard, La médecine entre savoirs et pouvoirs, Paris 1981, chap. 3.

5 Paris, archives of the Académie de médecine (henceforth AAM) V52, "Lettre du préfet des Landes au Comité central, 27 septembre 1811 « (V indicates the "Vaccine» collection in the archives). Compulsory vaccination was established in Sweden in 1816 and in Great Britain in 1856: Peter Baldwin, Contagion and the State, Cambridge 1999, p. 54-266. On the late adoption of compulsory vaccination in France, see Lion Murard, Patrick Zylberman, L'hygiène dans la République. La santé publique ou l'utopie contrariée 1870-1918, Paris 1986.

6 Jean Delumeau, Daniel Roche, Histoire des pères et de la paternité, Paris 1990. The father "stands in for the law, corrects habits and trains obedience $«$ : Pierre-Antoine Fenet, Recueil complet des travaux préparatoires du Code civil, n 51, vol. 10, Paris 1927, p. 486.

7 Paris, Archives nationales (henceforth AN) F 97, p. 119 (F indicates the collection »Police sanitaire et hygiène publique» in the Archives nationales).

8 Peter Sköld, »From Inoculation to Vaccination: Smallpox in Sweden in the Eighteenth and Nineteenth Centuries«, in: Population Studies 50 (1996), p. 247-262.

9 The French case has been studied well in two important books: YvesMarie Bercé, Le chaudron et la lancette, Paris 1984; Pierre Darmon, La longue traque de la variole, Paris 1985. See also Olivier Faure, "La vaccination dans la région Lyonnaise au début du XIXe siècle: résistances ou revendications populaires«, in: Cahiers d'histoire 29 (1984), p. 191-209; and, for England, Deborah Brunton, The Politics of Vaccination. Practice and Policy in England, Wales, Ireland, and Scotland 1800-1874, Rochester 2008.

10 Nadja Durbach, Bodily Matters. The Anti-Vaccination Movement in England 1853-1907, Durham 2005.

11 David Arnold, Colonizing the Body. State Medicine and Epidemic Disease in Nineteenth Century India, Berkeley 1993; Andrea Rusnock, "Catching Cowpox: the Early Spread of Smallpox Vaccination 1798$1810 \lll$, in: Bulletin of the History of Medicine 83 (2009), p. 17-36.

12 AN F8 125, "Avis. Inoculation de la vaccine. Le préfet aux habitants du département des Deux-Sèvres«.

13 Peter Becker, William Clark, "Introduction«, in: Peter Becker, William Clark (eds.), Little Tools of Knowledge. Historical Essays on Academic and Bureaucratic Practices, Ann Arbor 2001, p. 1-34.

14 AAM MS 728, Arrêté du ministre de l'intérieur portant formation d'une société centrale de vaccine.

15 AAM V1, Comité de la vaccine, séance du 13 Nivôse an XII (4 janvier 1804).

16 Jean-Baptiste Fressoz, »Petite histoire philosophique du risque et de l'expertise à propos de l'inoculation et de la vaccine. 1750-1800«, in: Sezin Topçu, Cecile Cuny, Kathia Serrano-Velarde (eds.), Savoirs en débat, Paris 2008, p. 197-225.
17 Jeremy Bentham, "Essays on the Subject of the Poor Laws«, in: Michael Quinn (ed.), Writings on the Poor Laws, vol. 1, Oxford 2001, p. 136.

18 "It was seen as a brilliant chimera or as pure charlatanism for some time. I admit that at first I could not rid myself of this unfavorable impression«: Louis-Armand Mongenot, De la vaccine considérée comme antidote de la petite vérole, Paris 1802, p. 4.

19 François-Ignace Goetz, De l'inutilité et des dangers de la vaccine, prouvé par les faits, Paris 1802, p. 87.

20 Jean-Sébastien Vaume, Les dangers de la vaccine, Paris 1801, p. 48. Joseph Bressy, a doctor from Montpellier, was not against the vaccine if a way could be found to purify it: Joseph Bressy, Théorie de la contagion et son application à la petite vérole, à la vaccine, à leurs inoculations et à l'hygiène, Paris 1802.

21 Jean Verdier, Tableaux analytiques et critiques de la vaccine et de la vaccination, Paris 1801.

22 Marcus Herz, »Über die Brutalimpfung und deren Vergleichung mit der humanen «, in: Journal der practischen Arzneykunde und Wundarzneykunst 12, Berlin 1801, p. 1-109, at p. 3. See the commentary by Grégoire Chamayou, Les corps vils. Expérimenter sur les corps humains aux XVIII e et XIXe siècles, Paris 2008. The Comité read Herz's text with care; see AAM V1, Herz, "L'inoculation brutale«.

23 Harry Marks, La médecine des preuves. Histoire et anthropologie des essais cliniques (1900-1990), Paris 1999; Christian Bonah, L'expérimentation humaine. Discours et pratiques en France 19001940, Paris 2007.

24 The Comité de vaccine, founded under the aegis of powerful philanthropists (bankers, ministers, senators), brought together prominent Parisian doctors who worked for the diffusion of the vaccine.

25 Chamayou, Les corps vils, p. 21-94.

26 Chappon counted 207 cases of post-vaccination smallpox, 39 deaths and 115 diverse symptoms or illnesses: Pierre Chappon, Traité historique des dangers de la vaccine, suivi d'observations et de réflexions sur le rapport du Comité central de vaccine, Paris 1803. In AAM V30d2, one finds numerous letters addressed to Husson from parents relating the resulting accidents and recurrences.

27 According to Bousquet, the vaccine fails twice as often when it is stored on glass plates or in capillary tubes: Jean-Baptiste Bousquet, Nouveau traité de la vaccine et des eruptions varioleuses ou varioliformes, Paris 1848, p. 240.

28 Henri-Marie Husson, "Sur la vaccine«, in: Journal de médecine, chirurgie, pharmacie 1 (1800), p. 259-267, at p. 266.

29 AAM V57, "Caqué à Husson«, 21 nivôse Year IX (11 January 1801).

30 AAM V57, "Husson à Caqué«, 6 nivôse Year IX (6 January 1801).

31 Jean-Antoine Chaptal, Mes souvenirs sur Napoléon, Paris 1893, p. 19.

32 AAM V2, "Le Comité à Chaptal«, 15 Frimaire Year IX (6 December 1800).

33 AAM V1, "Lettre d'Auglanier médecin à l'hôpital de Marseille à Thouret«, 18 Germinal Year IX (8 April 1801). Emphasis mine.

34 Bercé, Le chaudron et la lancette, p. 70.

35 Bousquet, Nouveau traité de la vaccine, p. 47.

36 AN F8 125, „Etat des individus vaccines par le soussigné Bernardin Piana«, 1812.

37 Rapport du Comité central de vaccine, Paris 1803, p. 255-259.

38 Ibidem, p. 117.

39 Ibidem, p. 97.

40 Ibidem, p. 203, 330. A number of parents asked for this test when their child experienced post-vaccination eruption.

41 P.-L. Delaloubie, Essai sur l'emploi du fluide vaccin pris sur une personne atteinte de maladie ou de vice héréditaire, ou d'affection quelconque. Ce fluide peut-il être nuisible ou sans danger?, Thesis 
from the Faculté de médecine de Paris, 1805. Richerand, who is often cited to prove the non-transmissibility of diseases, seems not to have conducted more than one experiment of this type: Anthelme Richerand, "Observations sur la vaccine«, in: Journal de médecine, chirurgie, pharmacie 2 (1801), p. 113-117, at p. 114.

42 Antoine Portal et al., Rapport fait au nom de la commission nommée par la classe des sciences mathématiques et physiques, pour l'examen de la méthode de préserver de la petite vérole par l'inoculation de la vaccine, Paris 1803.

43 Edward Jenner, The Evidence at Large as Laid before the Committee of the House of Commons, Respecting Dr Jenner's Discovery of Vaccine Inoculation, London 1805, p. 172-174.

44 Louis Valentin, Résultats de l'inoculation de la vaccine dans les départements de la Meurthe, de la Meuse, des Vosges et du HautRhin, Nancy 1802, p. 32.

45 AAM V51, „Procès verbal de l'inoculation variolique ou contre épreuve«, 8 Ventôse Year X (26 February 1802).

46 François-Ignace Goetz, „Au rédacteur «, in: Moniteur universel, 10 Brumaire Year IX (1 November 1800).

47 François-Ignace Goetz, Traité de la petite vérole et de l'inoculation, Paris 1798, p. 59; Mathieu-Antoine Salmade, Instruction sur la pratique de l'inoculation de la petite vérole, Paris 1799, p. 55.

48 An isolated hypothesis is never tested, but instead a network of hypotheses or implicit beliefs. See Pierre Duhem, La théorie physique, Paris 1906. Duhem's thesis on the under-determination of the theory of experimentation is a foundation of sociological analysis of experimentation and technological tests: Harry Collins, Changing Order. Replication and Induction in Scientific Practice, Chicago, London 1985.

49 Edward Jenner, Inquiry into the Causes and Effects of the Variolae Vaccinae, London 1798, p. 7.

50 Derrick Baxby, "The Genesis of Edward Jenner's Inquiry of 1798. A Comparison of the Two Unpublished Manuscripts and the Published Version«, in: Medical History 29 (1985), p. 193-199.

51 Norman Beale, Elaine Beale, »The Ingen Housz-Jenner Correspondence Revisited«, in: Medical History 49 (2005), p. 79-98.

52 Michel Foucault, Naissance de la clinique. Une archéologie du savoir médical, Paris 1963, p. 88-105.

53 Rapport du Comité central de vaccine, p. 77.

54 Henri-Marie Husson, Recherches historiques et médicales sur la vaccine, Paris 1801, p. 32-36.

55 Or classification of diseases. Linnaeus exhorted botanists to only consider form, proportion, number and position as characteristics: Michel Foucault, Les mots et les choses. Une archéologie des sciences humaines, Paris 1966, p. 144-150. The botanical system served as a model for nosology. See François Boissier de Sauvages, Nosologie méthodique, vol. 1, Lyon 1772, p. 98-99.

56 Henri-Marie Husson, "Réflexions sur la vaccine«, in: Recueil périodique de la société de médecine 10 (year IX), p. 118.

57 Rapport du Comité central de vaccine, p. 67.

58 Member of the Académie royale de peinture in 1789, he was named the painter and illustrator of the École de médecine of Paris in 1794.

59 Ibidem, p. 26.

60 Michael Lynch, „Discipline and the Material Form of Images: An Analysis of Scientific Visibility«, in: Social Studies of Science 15 (1985), p. 37-66.

61 François Fournier, Essai historique et pratique sur l'inoculation de la vaccine, Bruxelles, Paris 1802, p. 14-19.

62 Pierre-François Rayer, Traité théorique et pratique des maladies de la peau, vol. 1, Paris 1826, p. 421

63 Anatomical atlases had been charting the healthy body for a long time. However, the representation of pathologies aimed to display extraordinary cases rather than to define types.

64 Georges Cuvier, Rapport historique sur les progrès des sciences naturelles depuis 1789 et sur leur état actuel, Paris 1810, p. 343.

65 Goetz, De l'inutilité, p. 25.

66 On agnotology or the fabrication of ignorance see Robert N. Proctor, Londa Schiebinger (eds.), Agnotology. The Making and Unmaking of Ignorance, Stanford 2008.

67 AAM V6, "Lettre de Fouché à Sauvo, rédacteur du Moniteur universel«, 25 July 1809, which compelled him to present the articles to the Comité. The censorship must have existed before 1809.

68 AN F $^{8} 110$, »Rapport fait au Comité de vaccine sure la vaccination dans le department de l'Hérault par M. Vigaroux«.

69 Circular, 14 Germinal, Year XII (4 April 1804).

$70 \mathrm{AN} \mathrm{F}^{8} 113$, the minister to the prefect of the Loire, 2 August 1810: "This authentic tableau of the parents' carelessness seems to me to be one of the most powerful ways to force as yet undecided families to finally resort to a method which will protect their children and will spare them from the shame."

71 AAM V54.

72 AAM V63d3, Orne, "État des vaccinations de Gavelon«, 1811.

73 AAM V57, "État des personnes vacinées par J.-B. Taulin, résident à Eurville, adjoint du Comité de vaccine de Saint-Dizier«, 1808.

$74 \mathrm{AN} \mathrm{F}^{8} 113$, "Le $\mathrm{D}^{\mathrm{r}}$ Valteau au préfet de Loire inférieure«, 21 August 1813.

75 AAM V25, "Lettre du Dr Rabasse médecin à Serres, à M. le préfet du département des Hautes-Alpes«, 12 April 1820.

76 Antoine Drouet, Instituts vaccinogènes et variole. Études statistiques portant sur la ville de Lyon, Lyon 1897.

77 Dominique Latour, Réfutations de quelques préjugés sur la vaccine, 1823, p. 14; Jean-Étienne Thorel, Dissertation sur les préjugés populaires qui s'opposent à l'adoption générale de la vaccine, Strasbourg 1823; Bousquet, Nouveau traité de la vaccine. On the critique of vaccine as contamination, see primarily Durbach, Bodily Matters; Dorothy Porter, Roy Porter, »The Politics of Prevention. Anti-vaccinationism and Public Health in Nineteenth-Century England», in: Medical History 32 (1988), p. 231-252; Alison Bashford, "Foreign Bodies. Vaccination, Contagion and Colonialism in the Nineteenth Century", in: Alison Bashford, Claire Hooker (eds.), Contagion. Historical and Cultural Studies, London, New York 2001, p. 39-60.

78 The anti-vaccine movement was an early symptom of the medical, social and racial aspects of degeneration. See Hector Carnot, Petit traité de vaccinométrie, Paris 1857; Henri Verdé-Delisle, De la dégénérescence physique et morale de l'espèce humaine déterminée par le vaccin, Paris 1855; Armand Bayard, Influence de la vaccine sur la population ou de la gastro-entérite varioleuse avant et depuis la vaccine, Paris 1855. Indeed, the great theoretician of degeneration, Bénédict Augustin Morel, took care to distinguish his theories from those of the anti-vaccinators: Bénédict Augustin Morel, Traité des dégénérescences physiques, intellectuelles et morales de l'espèce humaine, Paris 1857, p. 560. See also Daniel Pick, Faces of Degeneration. A European Disorder (c. 1848-1918), Cambridge 1989.

79 Louis-Adolphe Bertillon, Conclusions statistiques contre les détracteurs de la vaccine, précédées d'un essai sur la méthode statistique appliquée à l'étude de l'homme, Paris 1857.

80 In 1877, Leicester authorities developed a very strict quarantine system: people affected by smallpox were identified and isolated. At the beginning of the century, the Leicester method became complementary (or, according to anti-vaccinators, an alternative) to vaccination: Stuart M. Fraser, "Leicester and Smallpox: the Leicester Method«, in: Medical History 24 (1980), p. 315-332. 
81 Rapport du Comité central de vaccine, p. 379. See also the Journal du soir n¹025 (25 Ventôse, year IX). Vaccinations were done with pus from the Reims cow, see »Extrait d'un rapport du Comité medical de Reims, sur la vaccine«, in: Journal de médecine, chirurgie, pharmacie 1 (1800), p. 326; „Comité médical établi à Paris pour l'inoculation de la vaccine, séance du 23 ventôse«, in: Journal de médecine, chirurgie, pharmacie 2 (1801), p. 68.

82 Doctors distinguished three phases of the disease: the primary phase, which was manifested by a hard chancre on the genital organs; the secondary phase which appeared from several weeks to several months after the primary phase, characterized by a wide variety of dermatological flora; and finally the tertiary phase, which appeared several years after the first symptoms and was manifested by neurological and cutaneous illnesses, diseases of the bone, and in most cases death.

83 Alain Corbin, "La grande peur de la syphilis«, in: Jean-Pierre Bardet et al. (eds.), Peurs et terreurs face à la contagion. Choléra, tuberculose, syphilis XIXe - XXe siècles, Paris 1988, p. 328-348.

84 One finds numerous references to these situations in Ambroise Tardieu, Étude medico-légale sur les maladies produites accidentellement ou involontairement, Paris 1879.

85 Charles-Victor Boucaud, Inoculation d'accidents secondaires syphilitiques, Lyon 1860. The context of this experiment and its moral critique were thoroughly studied by Alex Dracobly, "Ethics and Experimentation on Human Subjects in Mid-nineteenth-century France. The Story of the 1859 Syphilis Experiments«, in: Bulletin of the History of Medicine 77 (2003), p. 332-366; see also Chamayou, Les corps vils, p. 299. Tardieu emphasises the novelty of the notion of consent: Tardieu, Étude medico-légale, p. 280.

86 Rayer, Traité, p. 611-612.

87 Alexandre Viennois, "De la transmission de la syphilis par la vaccination«, in: Archives générales de médecine, 5e série, 15 (1860), p. 641-671. Most of the reported cases are Italian. Indeed the Italian medical reviews seem less timid. The Annali Universali di Medicina of Milan had in fact published a number of articles on the subject from 1824.

88 Gustave Lanoix, Étude sur la vaccination animale, 1866.

89 One situation involving hundreds of children at Auray in Brittany had a profound effect. See Gustave Closmadeuc, Examen critique des documents relatifs à l'epidémie de syphilis vaccinale d'Auray en 1866, Paris 1870; Eugène Bourdais, Sur les accidents graves qui ont suivi la vaccination de 130 enfants dans les environs d'Auray, Paris 1870. On the problem of contamination through the bovine vaccine, see the numerous references given by Alexandre Layet, Traité pratique de la vaccination animale, Paris 1889, p. 88-91.

90 Charles Montesquieu, Lettres persanes, Amsterdam 1760, p. 232. According to the same author, "The gentleness of the government contributes marvelously to the propagation of the species«, ibidem, p. 343.

91 Paul-Henri d'Holbach, Éthocratie ou le gouvernement fondé sur la morale, Amsterdam 1776, foreword.

92 Nicolas de Condorcet, "Tableau général de la science, qui a pour objet l'application du calcul aux sciences politiques et morales«, in: Journal d'instruction sociale 1 (1793), p. 105-128, at p. 109. 


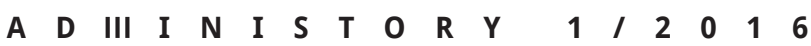

\section{Abstract}

The advent of smallpox vaccine in France in 1800 inaugurates a new relationship between administration, public health and the definition of medical facts. As Napoleon himself refused to establish compulsory vaccination, a Comité de vaccine was established so as to impose the idea of a riskless vaccine protecting forever from smallpox. This article studies how human experimentation, clinical experience, medical imagery and statistics maintained the idea of a perfect vaccine for six decades, despite the multiplication of cases of post-vaccination smallpox and vaccine contaminations.

\section{About the Author}

Jean-Baptiste Fressoz's research is at the crossroad between history of science, history of technology and environmental history. Formerly lecturer at Imperial College London, he is now a Senior researcher at the Centre National de la Recherche Scientifique (Centre Alexandre Koyré). He is the author of The shock of the Anthropocene. The Earth, history and us, Verso, 2016, (with Christophe Bonneuil) and L'Apocalypse joyeuse. Une histoire du risque technologique, Paris, Le Seuil, 2012. He is currently working on a global history of climatic knowledge since the 16th Century. 